\title{
OBRAZ MATKI BOŻEJ LATYCZOWSKIEJ. ANALIZA I INTERPRETACJA
}

Kult Maryi jako Bogurodzicy istnieje w Kościele od początku, o czym świadczą Dzieje Apostolskie, najstarsze znane modlitwy (Pod Twoja obronę, III w.) i przedstawienia w sztuce wczesnochrześcijańskiej (katakumby Pryscylli, Sarkofag dogmatyczny). Naukę o Bożym rodzicielstwie Maryi, oficjalnie potwierdził Sobór Efeski (431). Podkreślając jedność Osoby Chrystusa stwierdził, że Maryja jest prawdziwie Matką Boga (Theotokos). Nauka Soboru przyczyniła się do rozpowszechnienia w sztuce chrześcijańskiej, wizerunku tronującej Matki Bożej z Dzieciątkiem na ręku.

W tradycji wschodniej ikonograficzne ilustracje dogmatu o Bożym rodzicielstwie są liczne i trudne do usystematyzowania. Najczęściej wymienia się typy: Hodegetrii i Eleusy. Na Zachodzie Kościoła znanym i czczonym wizerunkiem jest Salus Populi Romani (Ocalenie Ludu Rzymskiego), znajdujący się w Bazylice Santa Maria Maggiore w Rzymie. Obraz Matki Bożej Latyczowskiej, który jest przedmiotem opracowania, jest jego kopią.

\section{Historia obrazu}

Ok. 1606 roku biskup kamieniecki Paweł Wołucki sprowadził do Latyczowa dominikanów, którzy otrzymali od papieża Klemensa XVIII kopię obrazu Salus Populi Romani, nieznanego malarza, jako błogosławieństwo na pracę misyjną.

Obraz jest datowany na XVI wiek, czego nie wykluczają badania konserwatorskie ${ }^{1}$. Prawdopodobnie z Rzymu został przywieziony między 1594-1597 rokiem. Kiedy dominikanie przybyli do Latyczowa (1606), obraz został umiesz-

* Renata Wierna - dr teologii, mgr historii sztuki; nauczyciel szkół średnich w Warszawie; e-mail: heyne_wierna@onet.eu

ORCID 0000-0003-4832-1578

${ }^{1}$ Por. H. I. Szumił, „Nigdym ja ciebie ludu nie rzuciła”. Z dziejów latyczowskiej Ikony, Sandomierz 2015, s. 306; taż, Do Ciebie wołamy, Orędowniczko nasza. Modlitwy i pieśni do Matki Bożej Latyczowskiej, wybór i oprac. H.I. Szumił, Lublin 2016. 
czony w kaplicy ufundowanej przez Potockich. W 1648 roku, w obawie przed najazdem Chmielnickiego, dominikanie zabrali obraz do Lwowa. Do Latyczowa powrócił w 1772 roku i pozostał tam do 1917 roku. W czasie pierwszej wojny światowej przebywał w Pietniczanach, potem w Winnicy, a w 1918 roku powrócił do Latyczowa. Pozostał tam do 1920 roku, kiedy to w obawie przed bolszewikami został wywieziony do Warszawy. Ze stolicy został przewieziony do kościoła parafialnego w Lubomlu (1930-1935), a następnie do katedry w Łucku (19351945). W 1945 roku został wywieziony do Lublina i do 2014 roku znajdował się w kaplicy Sióstr Służek NMP Niepokalanej (przy ul. I Armii Wojska Polskiego 9). W 2014 roku został przeniesiony do kościoła pw. Matki Bożej Różańcowej w Lublinie, przy ul. Bursztynowej $20^{2}$.

W ciągu swej historii obraz był kilkakrotnie restaurowany, ale nie zachowała się szczegółowa dokumentacja prac konserwatorskich. Ostatnią gruntowną renowację przeprowadzono w 2014 roku, w pracowni konserwatorskiej w Lublinie ${ }^{3}$.

\section{Stan badań}

W 2015 roku ukazała się praca H. I. Szumił ,Nigdym ja ciebie ludu, nie rzucita". Z dziejów latyczowskiej Ikony ${ }^{4}$. Jest to całościowe opracowanie historii obrazu Matki Bożej Latyczowskiej i jego kultu, począwszy od XVI wieku do czasów współczesnych. Publikacja zawiera także kompletną bibliografię przedmiotu (ponad 200 pozycji). Autorka skrzętnie odnotowała w układzie chronologicznym nie tylko artykuły, ale także wzmianki o obrazie. Przeważają publikacje o charakterze historycznym. Spośród nich na uwagę zasługują: F. Zgierskiego, Historyczny opis Cudownego Obrazu Najświętszej Maryi Panny i kościoła w Latyczowie z dodatkiem modlitw i pieśni pobożnych ${ }^{5}$ oraz Historia Cudownego Obrazu Najświętszej Maryi Panny Latyczowskiej znajdującego się w katedrze tuckiej ${ }^{6}$. Nowszy artykuł jest autorstwa J. Kani, Miejsca szczególnej czci Matki Bożej na Lubelszczyź$n i e^{7}$ oraz książka M. Koprowskiego, Kresy we krwi ${ }^{8}$. Należy wspomnieć również o dwóch publikacjach M. Dębowskiej: Obraz Matki Bożej Latyczowskiej w diecezji tuckiej (1930-1945) ${ }^{9}$ oraz Matka Boża Latyczowska na Wołyniu 1930-194510.

\footnotetext{
${ }^{2}$ Tamże, s. 71-218.

${ }^{3}$ Tamże, s. 295-307.

${ }^{4}$ H.I. Szumił, „Nigdym ja ciebie ludu, nie rzuciła”. Z dziejów latyczowskiej Ikony, Sandomierz 2015.

${ }^{5}$ F. Zgierski, Historyczny opis Cudownego Obrazu Najświętszej Maryi Panny i kościoła w Latyczowie z dodatkiem modlitw i pieśni pobożnych, (Kraków 1876).

${ }^{6}$ Historia Cudownego Obrazu Najświętszej Maryi Panny Latyczowskiej znajdującego się w katedrze tuckiej, Łuck 1936.

${ }^{7}$ J. Kania, Miejsca szczególnej czci Matki Bożej na Lubelszczyźnie (Matka Tułaczy i Piastunka Nadziei), „Wiadomości Diecezjalne Podlaskie”, 61 (1992) nr 1-3, s. 73-74.

${ }^{8}$ M. Koprowski, Kresy we krwi, Warszawa 2011.

${ }^{9}$ M. Dębowska Obraz Matki Bożej Latyczowskiej w diecezji tuckiej (1930-1945), „Archiwa Biblioteki i Muzea Kościelne”, 105 (2016) s. 25-43.

${ }^{10}$ Taż, Matka Boża Latyczowska na Wołyniu 1930-1945, Biały Dunajec-Ostróg 2017.
} 
W historiografii brak jest szczegółowego opracowania ikonografii i teologii obrazu. Jedyną pozycją jest książka A. Wolińskiej-Wójtowicz, Matka Boża Latyczowska, która powstała jako podsumowanie konserwacji obrazu, jednak nie zagłębia się ona szczegółowo w teologię i ikonografię wizerunku ${ }^{11}$.

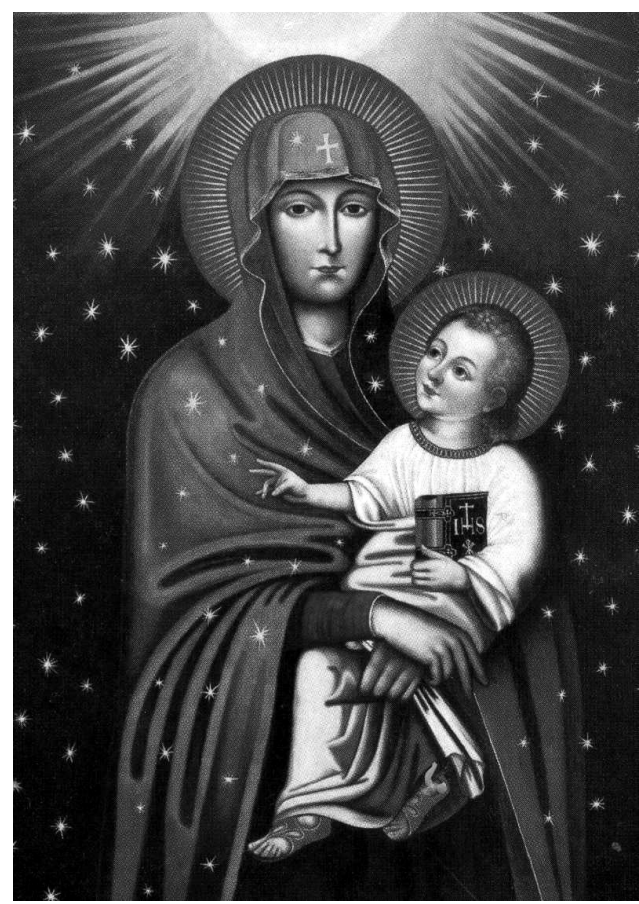

Fot. ze zbiorów autorki.

\section{Opis formalny}

Obraz Matki Bożej Latyczowskiej został wykonany w technice tempery (ewentualnie $\mathrm{z}$ domieszką oleju) na płótnie naciągniętym na deskę ${ }^{12}$. Posiada wymiary $128,5 \times 92 \mathrm{~cm}^{13}$. Przedstawia Maryję w pozycji stojącej, w ujęciu do kolan. Maryja trzyma Dzieciątko Jezus na lewym przedramieniu, podtrzymując Je prawą ręką. W lewej ręce trzyma białą chusteczkę. Jest ubrana w suknię ciemnoczerwoną, ozdobioną pod szyją złotą lamówką. Wierzchnią szatę stanowi szafirowy maforion, także obszyty złotą lamówką i ozdobiony złotym krzyżykiem na wysokości czoła. Widoczna wewnętrzna strona maforionu jest oliwkowozielona. Miękko otula on twarz Maryi, tak że nie są widoczne włosy.

Dzieciątko Jezus jest ubrane w biały chiton, ze złotym wykończeniem pod szyją, a od pasa jest owinięte jasnozłotym himationem, bogato drapowanym. Na

${ }^{11}$ A. Wolińska-Wójtowicz, Matka Boża Latyczowska, Lublin 2014.

${ }^{12}$ Por. Szumił, ,Nigdym ja ciebie ludu nie rzuciła”, s. 306.

${ }^{13}$ Prace konserwatorskie wykazały, że pierwotne wymiary obrazu, z wyjątkiem dolnej krawędzi, zostały zachowane. 
bosych stopach ma sandały. Lewą ręką podtrzymuje zamknięty Ewangeliarz, w ozdobnej oprawie, a prawą rękę ma wyciągniętą w geście błogosławieństwa. Wyraz Jego twarzy jest delikatny, z charakterystyczną dla malarstwa ikonowego słodyczą.

Maryja spogląda przed siebie. Jej oblicze jest poważne i zamyślone. Z kolei Jezus spogląda na prawo, spojrzeniem skupionym i przenikliwym. Na Jego twarzy widać delikatny uśmiech. Głowy Maryi i Dzieciątka są otoczone promienistymi nimbami w kolorze starego złota.

Tło obrazu jest ciemnogranatowe, z widocznym u góry fragmentem świetlistego kręgu, z rozchodzącymi się jasnoniebieskimi promieniami. Całe przedstawienie jest ozdobione deszczem spadających gwiazdek, które nadają mu cechę dekoracyjności. Zauważa się troskę artysty o przedstawienie detali, światła załamującego się w fałdach szat, delikatności dłoni Maryi, kunsztownych sandałków Dzieciątka.

Wcześniejsze opisy obrazu różnią się co do kolorystyki i niektórych szczegółów przedstawienia (np. pierścień na palcu Maryi). Rozbieżności te wynikają $\mathrm{z}$ faktu częściowego przemalowania obrazu w trakcie jego historii. Dopiero ostatnia restauracja w 2014 roku odsłoniła pierwotny wizerunek:

Okazało się, że perełka w prawej dłoni Dzieciątka była domalowana na ostatniej warstwie werniksu, a na dłoni Madonny nie ma pierścienia opisywanego w literaturze. Płaszcz Matki Boskiej był miejscami przemalowany zielenią, gdyż pierwotny błękitny odcień szaty uległ z czasem zmianie (...). Ponadto partia płaszcza pożółkła pod wpływem oleju z późniejszych retuszy (...). Powyżej głowy Matki Boskiej odsłonięto spod przemalowania świetlisty krąg $\mathrm{z}$ promieniami. W partii tła oraz na płaszczu Madonny odnaleziono liczne ślady wcześniej niewidocznych gwiazdek, z których tylko znajdujące się w górnej strefie kompozycji zachowały resztki złocenia ${ }^{14}$.

\section{Analiza stylistyczna}

Kopie Salus Populi Romani pojawiły się w Polsce pod koniec XVI wieku' ${ }^{15}$. Przeszly one pewną ewolucję przedstawienia pod wpływem malarstwa zachodniego. W zasadzie wpływ malarstwa zachodniego na sztukę bizantyńską notuje się już od czasu upadku Bizancjum, ale zjawisko to nasiliło się w połowie XVII wieku. Dotyczyło teologii ikony, jak i kanonu malarskiego. Ale w Europie Środkowej (dzisiejsza Rzeczpospolita i Ukraina zachodnia) wiązało się to bardziej $z$ kanonem malarskim niż teologią ${ }^{16}$. Przykładem takiej ewolucji jest właśnie obraz Matki Bożej Latyczowskiej. Aby to wykazać konieczna jest analiza porównawcza obu wizerunków, w zakresie kompozycji, kolorystyki, światłocienia i ekspresji.

${ }^{14}$ Protokół konserwacji obrazu, cyt. za: Szumił, „, Nigdy ja ciebie ludu, nie rzuciła”, s. 306-307.

${ }_{15}$ Tamże, s. 73; Z. Janiec, Kult Maryi w Polsce na przestrzeni dziejów. Zarys problematyki, Sandomierz 2013, s. 194-195.

${ }^{16}$ Por. B. Dąb-Kalinowska, Ikony. Najpiękniejsze ikony w zbiorach polskich, Olszanica 2008, s. 13. 


\subsection{Kompozycja}

Układ kompozycyjny latyczowskiego obrazu jest wiernie powtórzony z dzieła rzymskiego. Na wizerunku rzymskim Maryja jest przedstawiona frontalnie, ale w lekkim półobrocie do widza. Jej spojrzenie w prawą stronę nadaje przedstawieniu pewne cechy dynamizmu. Pod tym względem przedstawienie z Latyczowa jest bardziej statyczne. Natomiast postać Dzieciątka w jednym jak drugim obrazie została przedstawiona $\mathrm{w}$ ujęciu $3 / 4$.

Wizerunek rzymski jest zdecydowanie dwuwymiarowy. Jego złote tho eliminuje iluzję przestrzeni. Postaci są przedstawione płaszczyznowo, sprawiają wrażenie odmaterializowanych. W górnych rogach są widoczne greckie napisy, identyfikujące osoby przedstawiane. Dopełniają one wizerunek i nadające mu sakralno-mistyczną wartość. Są to MP („Matka Boga”) i OV („Ten, Który Jest”). Kompozycję zamyka bordiura z motywem złotych rombów. Tworzy ona malarską ramkę dla ikony i w myśl teologii wschodniej, stanowi ochronę jej świętości.

$\mathrm{Na}$ obrazie z Latyczowa malarz zastosował modelunek światłocieniowy, przez co przedstawiane osoby są bardziej przestrzenne i cielesne. Także wprowadzenie tła ciemnogranatowego z gwiazdami, przypominającego nocne niebo, stwarza wrażenie pewnej przestrzenności i głębi (perspektywa barwna). Nie jest to już złote tło, transcendentne, ale konkretna przestrzeń, choć ponadziemska.

$\mathrm{Na}$ obrazie rzymskim Maryja spogląda w prawym kierunku, a na obrazie z Latyczowa patrzy na lewo. Natomiast wzrok Dzieciątka na obu obrazach jest skierowany na prawo. Na obrazie z Latyczowa nie ma napisów.

Na obu obrazach występuje takie same skrzyżowanie dłoni Maryi i takie same ułożenie palców prawej dłoni. W lewej ręce Maryja trzyma białą chusteczkę, przełożoną przez kciuk. Na obrazie z Latyczowa nie ma pierścienia.

\subsection{Kolorystyka}

Wizerunek rzymski przedstawia Maryję ubraną w ciemnoniebieski maforion, ozdobiony złotą lamówką. Szatę spodnią stanowi purpurowa suknia. Tego samego koloru jest chiton Dzieciątka. Nimby Maryi i Dzieciątka są w kolorze starego złota.

Kolorystyka obrazu latyczowskiego jest podobna. Są to odcienie niebieskiego (maforion i tło), kolor czerwony (suknia Maryi), biały i złoty (ewentualnie żółty) - szaty Dzieciątka, nimby, gwiazdki i świetlisty krąg.

Obraz z Latyczowa jest starannie opracowany kolorystycznie. Przeważają barwy zimne, nieco stonowane. Wprowadzenie ciemnogranatowego tha, przyczyniło się do ożywienia pozostałych kolorów. Jest to szczególnie widoczne w przypadku koloru sukni Maryi, gdzie mocna czerwień została skontrastowana z niebieskim maforionem i biało-żółtą (jasnozłotą) szatą Jezusa.

Lśniąca biała szata Jezusa na obrzeżach przechodzi w odcień migotliwego, wibrującego fioletu. Stanowi mocny akcent kolorystyczny, sprawia, że widz najpierw zauważą postać Dzieciątka, a potem Maryję. Kolorystyka szat Jezusa jest zdecydowanie jaśniejsza. 


\section{3. Światlocień}

Ikona nie ma światłocienia, gdyż ukazuje rzeczywistość duchową, a nie materialną. W rzeczywistości Boskiej jest pełnia światła, dlatego nie może występować cień. Ikona zawiera wewnętrzne światło, które jest atrybutem Boskiej chwały. Symbolem tego światła jest właśnie złote tło. Stanowi ono także symboliczne odrzucenie ziemskiego czasu i przestrzeni.

Źródłem światła na ikonie są także Osoby Boskie. Emanują one nadprzyrodzone światło widoczne na ich rozjaśnionych obliczach lub na szatach w postaci połyskujących asystek. Taki rodzaj światła zawiera ikona Salus Populi Romani.

Na obrazie Matki Bożej Latyczowskiej światło wprowadza kontrasty jasnych i ciemnych partii. Jak na obrazach nowożytnych, występuje kilka źródeł światła. W części górnej źródłem światła jest promieniująca gwiazda, której blask przenika fragment tła, tworząc nad Maryją świetlistą jasność. Spadające złote gwiazdki, świetlnymi punktami oświetlają ciemność granatowego tła.

Nieco odmienny charakter ma światło zewnętrzne (spoza obrazu), padające z lewej strony. Różnicuje walorowo barwy, tworzy refleksy świetlne na promieniach aureoli, złotych lamówkach i na oprawie Ewangeliarza.

Najbardziej oświetloną postacią jest Jezus. Jego oblicze i biało-złota szata wręcz promienieją jasnością. Być może w ten sposób malarz chciał oddać efekt tzw. światła nadprzyrodzonego, charakterystycznego dla Osób Boskich. Sam Jezus powiedział o sobie: „Ja jestem światłością świata” (J 8,12).

\subsection{Ekspresja}

Na obrazie Salus Populi Romani, rysy twarzy Maryi są surowe i poważne, z podkreślonymi oczami i nosem, a małymi ustami. Natomiast twarz Dzieciątka przypomina oblicze dorosłego człowieka, z wysokim czołem i charakterystycznym zmarszczeniem brwi. Natomiast na obrazie z Latyczowa, rysy Maryi i Dzieciątka są bardziej regularne, twarze w kolorze cielistym z lekkim zaznaczeniem różem, w celu wydobycia wypukłości.

Na obu wizerunkach (rzymskim i latyczowskim), brak emocjonalnego związku pomiędzy Matką a Synem, ani Maryja, ani Dzieciątko nie zwracają na siebie uwagi. Poza Matki jest wdzięczna i naturalna, a Małego Jezusa ożywiona i pełna dziecięcego uroku.

Na ikonie rzymskiej środkiem obrazowania jest linia i kolor, tworzące harmonijną jedność, przez co obraz emanuje spokojem i ponadczasowym trwaniem. W obrazie latyczowskim dodatkowym środkiem jest światłocień. O ile na ikonie rzymskiej linia wydobywa kształty z jakiegoś niebytu, to na obrazie z Latyczowa, taką rolę pełni światło.

Tło ciemnogranatowe i spadające jak śnieg gwiazdy ukazują głębie kosmosu, a przez to wprowadzają nastrój tajemnicy. Tworzą sugestię niezwykłego zjawiska.

Obraz z Latyczowa nie jest wierną kopią obrazu Salus Populi Romanii. Oba dzieła różnią się stylistycznie. Obraz rzymski posiada wyraźne cechy stylu bizantyńskiego: płaszczyznowość postaci, złote tło, obfite drapowanie szaty, zwłaszcza Dzieciątka, charakterystyczne dla ikony napisy. Natomiast obraz z Latyczowa jest 
traktowany bardziej malarsko, postacie są miękko modelowane. W opracowaniu kolorystycznym zasadnicza różnica polega na rozjaśnieniu szat Jezusa. Próba osiągnięcia trójwymiarowości w obrazie latyczowskim, odcina go od dzieł sztuki bizantyńskiej.

Pod względem kompozycji i kolorystyki, obraz z Latyczowa zachowuje duże podobieństwa z obrazem Matki Bożej Śnieżnej z kolegiaty Bożego Ciała w Jarosławiu, datowanym na ok. 1570 rok, czyli mniej więcej na ten sam czas powstania.

$\mathrm{Z}$ punktu religijnego to, że obraz z Latyczowa nie jest wierną kopią ikony rzymskiej, nie umniejsza jego wartości,

ponieważ wszystkie powtórzenia, ile by ich nie namalowano, posiadają tę samą wartość sakralno-mistyczną, tę samą energię praobrazu, w niczym nie są lepsze od oryginału, z którego zostały sporządzone ${ }^{17}$.

\section{Analiza ikonograficzna}

Obraz Matki Bożej Latyczowskiej nie jest wierną kopią Salus Populi Romani. Pomija niektóre motywy (złote tło z ozdobną ramką, napisy, pierścień Maryi), a wprowadza nowe (ciemnogranatowe tło, świetlisty krąg nad głową Maryi, spadające gwiazdki) ${ }^{18}$.

\subsection{Przedstawienie Matki Bożej}

Maryja jest przedstawiona jako Bogurodzica. Jej szafirowy maforion symbolizuje łączność ze światem nadprzyrodzonym, ponieważ jest kolorem nie tylko nieba, które widzimy, ale także miejsca przebywania Boga. Tak je oglądali Mojżesz i starsi, którzy wstąpili na górę Synaj: „Ujrzeli Boga Izraela, a pod Jego stopami jakby jakieś dzieło z szafirowych kamieni, świecących jak samo niebo" (Rdz 24,10). Dlatego na ikonie Andrzeja Rublowa Trójca Święta, niebieskie szaty wędrowców zdradzają ich boskie pochodzenie. Kolor nieba jest też symbolem nieskazitelnej czystości i świętości. W ikonografii chrześcijańskiej, zwłaszcza w sztuce Kościoła zachodniego, został szczególnie powiązany z Maryją, która jest „łaski pełna”. Wewnętrzna strona maforionu jest koloru oliwkowozielonego. Podkreśla ona ludzką (ziemską) naturę Maryi.

Czerwony kolor sukni symbolizuje miłość do Boga jako ogień Ducha Świętego. W liturgii podkreśla się symboliczny związek pomiędzy barwą czerwoną a Duchem Świętym, dlatego w Uroczystość Zesłania Ducha Świętego używa się szat koloru czerwonego, a ikonografia czerpie z bogactwa liturgii. Kolor czerwony może też być symbolem godności królewskiej Maryi i Jej Boskiego macierzyństwa.

$\mathrm{W}$ teologii macierzyństwo Maryi jest powiązane z dogmatem o potrójnym dziewictwie $^{19}$, które początkowo symbolizowały trzy gwiazdki na szacie (dwie

${ }^{17}$ Tamże, s. 9.

${ }^{18}$ R. Wierna, Reikonografia obrazu Matki Bożej Latyczowskiej, w: Pod Twoja obronę... Sanktuaria Maryjne na Podolu, red. H.I. Szumił, Sandomierz 2018, s. 87-102.

19 „Maryja «była Dziewicą przy poczęciu swego Syna, Dziewicą jako brzemienna, Dziewicą jako karmiąca własną piersią, Dziewicą zawsze»”. Katechizm Kościoła Katolickiego (dalej: KKK), Poznań 1994, nr 510. 
na ramionach, jedna na wysokości czoła). $Z$ czasem zamiennie zaczęto stosować także krzyżyki (por. Maryja jako Orantka, XI w., mozaika w absydzie Soboru Sofijskiego). Na obrazie Salus Populi Romani i na obrazie latyczowskim dziewictwo Matki Bożej symbolizuje złoty krzyżyk na maforionie, na wysokości czoła.

Ciekawym motywem, ale rzadko spotykanym na ikonach, jest biała chusteczka (łac. mappula, mappa) trzymana przez Maryję. Występuje na kopiach obrazu Salus Populi Romani, ale także na mozaice z przełomu IX/X wieku (absyda Hagia Sophia, Konstantynopol), przedstawiającej Matkę Bożą tronującą, czy na ikonie ze złotej blachy (X w.), z wyobrażeniem Hodegetrii (Martwili, Gruzja) ${ }^{20}$.

Pierwotnie chustka ta miała zastosowanie praktyczne, służyła do ocierania potu i łez, a także przy posiłkach ${ }^{21}$. Z czasem, bogato zdobiona stała się niejako elementem stroju. I w tej funkcji występuje na mozaice bizantyńskiej w kościele San Vitale w Rawennie, gdzie jedna z dam orszaku cesarzowej Teodory, trzyma w ręku taką chusteczkę. Przyjęła się także jako znak rozpoczęcia igrzysk. Dyptyk konsularny Flawiusza Anastazjusza (517 r., kość słoniowa, Luwr) przedstawia scenę, w której Anastazjusz symbolicznym uniesieniem chusty ogłasza początek zmagań w cyrku ${ }^{22}$.

Od mappuli wywodzi się manipularz, pas tkaniny przypominający stułę, w kolorze szat liturgicznych, ozdobiony na środku krzyżykiem. Noszony był przez duchownych na lewym przedramieniu, w czasie sprawowania liturgii eucharystycznej. Jako element stroju liturgicznego używany był już w pierwszych wiekach. Początkowo, tak jak mappula, służył do wycierania potu i łez, z czasem stał się także znakiem gotowości do składania ofiary eucharystycznej. Od XII wieku był uroczyście przekazywany przez biskupa, w czasie święceń subdiakonatu ${ }^{23}$. Występuje na mozaice z w absydzie Soboru Sofijskiego w Kijowie (XI w.). przedstawiającej komunię Apostołów (na lewej ręce św. Wawrzyńca).

Manipularz symbolizował jedno z ośmiu błogosławieństw Chrystusa - „błogosławieni, którzy płaczą" (Mt 5,4), a więc nawiązywał do mappuli jako chusteczki do wycierania łez. Potwierdzeniem tego jest piękna modlitwa, która towarzyszyła jego nakładaniu: „Niech będę godny, Panie, nosić snop płaczu i bólu, abym z weselem odebrał zapłatę za pracę"24.

Wydaje się, że symbolikę chusteczki trzymanej przez Maryję na ikonach należy wiązać z symboliką manipularza, a nie mappuli. Przy takim założeniu, wprowadza ona akcent pasyjny do przedstawienia. Chociaż na wizerunku Maryja jest przedstawiona jako Bogurodzica, to jednocześnie nie przestaje być Matką Boleściwą.

${ }^{20}$ Por. K. Onasch, A. Schnieper, Ikony. Fakty i legendy, Warszawa 2002, s. 289.

21 Por. S. Kobiela, Matka Boża z chusteczka - encheirionem, „Series Byzantina”, 5 (2007) s. 34-38; Amalariusz z Metzu, Święte obrzędy Kościoła, II, 24, przekł. zbiorowy, w: Amalariusz z Metzu, Dzieła, t. 1, red. T. Gacia, Lublin 2017, s. 228-229 (Sudarium).

22 Por. Historia sztuki, t. 5: Bizancjum i islam, red. D. Fedor, Kraków 2010, s. 26.

${ }^{23}$ Por. Cz. Krakowiak, Manipularz, w: Encyklopedia katolicka, t. 11, Lublin 2006, kol. 1163.

${ }^{24}$ Tamże, kol. 1163. 


\subsection{Dzieciątko Jezus}

Dzieciątko Jezus jest przedstawione jako Emmanuel. Ten typ ikonograficzny nawiązuje do proroctwa Izajasza: „Dlatego Pan sam da wam znak: Oto Panna pocznie i porodzi Syna, i nazwie Go imieniem Emmanuel" (Iz 7,14). Imię Emmanuel z języka hebrajskiego znaczy „Bóg jest z nami”.

W sztuce bizantyńskiej Emmanuel stanowi symboliczne wyobrażenie Słowa Bożego, Logosu istniejącego odwiecznie przed Wcieleniem. Natomiast trzymany przez Maryję na ręku stanowi proklamację Wcielenia. Jest przedstawiany z obliczem dorosłego mężczyzny (wysokie zaokrąglone czoło, spojrzenie mędrca), bo chociaż narodził się jako Dziecię, to przecież jest odwiecznym Logosem.

Biała szata Jezusa nawiązuje do Przemienienia na Górze Tabor. Marek Ewangelista zapisał, że podczas tego wydarzenia „Jego odzienie stało się lśniąco białe, tak jak żaden na ziemi folusznik wybielić nie zdoła" $(9,3)$. Podczas Przemienienia, Bóg objawił Jezusa jako umiłowanego Syna, istniejącego przedwiecznie i posiadającego Jego chwałę ${ }^{25}$. Znakiem tej chwały jest właśnie biała szata, taka jak szata Boga z widzenia proroka Daniela: „Patrzyłem, aż postawiono trony, a Przedwieczny zajął miejsce. Szata Jego była biała jak śnieg” (Dn 7,9). Tę sama treść wyraża złoty himation, symbol Boskiego królowania i odbicie wiecznej chwały: „Wszechmocny będzie twą sztabą złota i stosem srebra dla ciebie” (Hi 22,25).

Dopełnienie powyższej interpretacji stanowi gest błogosławieństwa. Trzy palce złączone oznaczają jedność Trójcy Świętej, a dwa palce wyprostowane, w tym przypadku wskazujący i środkowy, wyrażają prawdę o podwójnej naturze (Boskiej i ludzkiej) Jezusa Chrystusa. Gest ten podkreśla ideę Chrystusa-Logosu, ale w Starożytności był też znakiem tego kto przemawia (naucza).

Ewangeliarz, bogato oprawiony, trzymany przez Jezusa w lewej ręce symbolizuje Słowo Boże. Wszystkie księgi Biblii w Jezusie otrzymują nowy sens. Do Jezusa były Prawem, sumą przykazań, których człowiek nie mógł wypełnić. Lecz kiedy przyszedł Jezus, wypełnił doskonale wolę Bożą zawartą w Starym Testamencie. Sam stał się Słowem Boga, które przemówiło w czasach ostatecznych. Dlatego na okładce Ewangeliarza jest Jego monogram.

Sandały na stopach Jezusa symbolizują godność i synostwo Boże. Kiedy syn marnotrawny powrócił do domu, ojciec kazał mu podać sandały na znak przywróconej łaski (por. Łk 15,22).

Ojcowie Kościoła, słowa Jana Chrzciciela: „Nie jestem godzien odwiązać rzemyka u Jego sandała" (J 1,27) interpretują jako obraz Wcielenia. Według tej interpretacji, nałożenie sandałów przez Chrystusa jest metaforą przyjęcia ludzkiej natury. Jest to tak wielka tajemnica, której rozum ludzki nie jest w stanie przeniknąć, czyli „rozwiązać rzemyka sandałów”. Św. Grzegorz z Nazjanzu pisze:

Nie może bowiem [oko ludzkie - RW] w żaden sposób zbadać, jak Słowo się wciela, jak najwyższy i ożywiający Duch ożywa w łonie Matki, jak Ten, który

25 Por. P. de Surgy, Przemienienie. Słownik teologii biblijnej, red. X. Leon-Dufour, przekł. K. Romaniuk, Poznań-Warszawa 1985, s. 807-808. 
nie ma początku, i istnieje, i poczyna się. Rzemykiem więc u obuwia jest wiązadło tajemnicy ${ }^{26}$.

Postać Dzieciątka (Emmanuela), przez gest błogosławieństwa i trzymaną księgę nawiązuje do typu Pantokratora.

\subsection{Niebo usiane gwiazdami}

Gwiazdy na wizerunkach Maryi występują w Jej przedstawieniach jako Madonny Apokaliptycznej, inspirowanych tekstem Apokalipsy: „Niewiasta obleczona w słońce, i księżyc pod Jej stopami, a na jej głowie wieniec z gwiazd dwunastu" (Ap 12,1). Próbą połączenia wizji apokaliptycznej z wizerunkiem latyczowskim jest srebrna sukienka obrazu, na której nimb Maryi otacza dodatkowo dwanaście gwiazd.

Gwiazdy na płaszczu Maryi występują w wizerunku z Guadalupe, powstałym w 1531 roku i jest niewykluczone, że mogły stanowić jakąś inspirację dla malarza obrazu z Latyczowa.

$\mathrm{Na}$ obrazie z Latyczowa gwiazdy nie stanowią ozdoby szaty Maryi, tylko swobodnie spadają na maforion i obok niej, ale nie spadają na Dzieciątko Jezus. Nad głową Maryi jest widoczny fragment świetlistego kręgu z odchodzącymi bladoniebieskimi promieniami, wskazującymi bardziej na gwiazdę, niż słońce. Wydaje się, że gwiazdy wykazują wyraźny związek z osobą Maryi.

Gwiazdy na nocnym niebie są znakiem majestatu Stwórcy, który „liczbę gwiazd oznacza, wszystkie je woła po imieniu" (Ps 147,4). Mogą być też obrazem piękna i wielkości świata stworzonego (por. Syr 43,9) ${ }^{27}$, a także obrazem zbawionych: „Mądrzy będą świecić jak blask sklepienia, a ci, którzy nauczyli wielu sprawiedliwości, jak gwiazdy na wieki i na zawsze" (Dn 12,3).

Ta ostatnia interpretacja wiąże się z obietnicą daną przez Boga Abrahamowi, że jego potomstwo będzie liczne jak gwiazdy na niebie: , «Spójrz na niebo i policz gwiazdy, jeśli zdołasz to uczynić»; potem [Pan - RW] dodał: «Tak liczne będzie twoje potomstwo». Abram uwierzył i Pan poczytał mu to za zasługe" (Rdz 15, 6). Interpretację powyższego tekstu w sposób poetycki wyraziła D. Forster: „Gdy kiedyś wypełni się liczba tych, którzy moca wiary zostali dziećmi Abrahama, wtedy też odsłoni się tajemnica tamtego świata, którą w milczeniu obwieszcza blask gwiazd"28. Taką wymowę ma mozaika (V w.) w Mauzoleum Galli Placydii, przedstawiająca złoty krzyż na nocnym niebie, usianym gwiazdami. Krzyż symbolizuje zwycięstwo Chrystusa, a gwiazdy chwałę zbawionych. Potwierdza to napis Salvus Mundi, na mozaice w absydzie kościoła św. Apolinarego in Classe w Rawennie (VI w.).

Wśród wybranych najjaśniej świeci Maryja, Matka łaski, przyzywana w Litanii Loretańskiej (XII w.) jako Stella Matutina. W swym ziemskim istnieniu, na

\footnotetext{
${ }^{26}$ Cyt. za: D. Forster, Świat symboliki chrześcijańskiej. Leksykon, Warszawa 2001, s. 448.

27 Tamże, s. 64-65.

${ }^{28}$ Tamże, s. 102.
} 
podobieństwo jutrzenki, wyprzedza Chrystusa-Słońce ${ }^{29}$. Pisze o tym św. Efrem Syryjczyk (IV w.): „Witaj, gwiazdo najjaśniejsza, witaj, przez ciebie zajaśniało Słońce sprawiedliwości" ${ }^{30}$.

Tytuł Maryi Gwiazda zaranna (jutrzenka) ma genezę o wiele wcześniejszą niż Litania Loretańska. Stefan ze Sjunu (VIII w.) nazywa Maryję Gwiazda zaranna, „na niebiesiech niezmiennie jaśniejącą"31.

Złote tło na obrazie Salus Populi Romani jest symbolem nadprzyrodzoności, a ciemnogranatowe przypominające nocne niebo na obrazie z Latyczowa wprowadza tajemniczy, nieogarnięty bezkres.

$\mathrm{Na}$ obraz Matki Bożej Latyczowskiej były nałożone metalowe sukienki. Osłony obrazu w tradycji bizantyńskiej pełnią one zarówno funkcję praktyczną (ochronną), jak też podkreślają sakralne znaczenie ikony osłaniając ją na podobieństwo relikwiarza. Nie są tylko kopią ikony, ale zyskują duchową autonomię ${ }^{32}$. Sukienki, które odtwarzają w sposób plastyczny układ szat, są charakterystyczne dla kultury zachodniej. I takie posiada obraz z Latyczowa.

Metalowe sukienki Maryi i Dzieciątka są ozdobione kwiatami i owocami granatu, natomiast tło pędami winnej latorośli. Zamiast mappuli, Maryja trzyma berło.

Owoce granatu symbolizują błogosławieństwo Boże, jako nagrodę za dochowanie wierności Prawu Bożemu, dlatego Ojcowie Kościoła widzą w granacie symbol Kościoła ${ }^{33}$. Winna latorośl ma bardzo bogatą symbolikę w Biblii i tradycji Kościoła. Przede wszystkim jest symbolem Chrystusa i Eucharystii.

\section{Interpretacja teologiczna}

Obraz Matki Boskiej Latyczowskiej jest przedstawieniem reprezentacyjnym i jednocześnie dogmatycznym. Ukazuje Maryję jako Bogurodzice, w połączeniu z ideą Jej dziewictwa i Boskiego macierzyństwa.

Maryja już przed narodzeniem Jezusa została przez św. Elżbietę nazwana „Matką mojego Pana” (Łk 1,43). Kościół naucza, że „Ten, którego poczęła jako człowieka z Ducha Świętego i który prawdziwie stał się Jej Synem według ciała, nie jest nikim innym jak wiecznym Synem Ojca, drugą Osobą Trójcy Świętej” (KKK 495). Dlatego od początku wyznaje, że Maryja jest Matką Bożą - Theotokos.

Przedstawienie na obrazie latyczowskim Jezusa jako syna Maryi wedhug ciała (Dzieciątko), z atrybutami wskazującymi na Syna Bożego, oczekiwanego Emmanuela, podkreśla właśnie Boskie macierzyństwo Maryi. Przedstawia Ją jako Tę, która od początku została napełniona „blaskami szczególnej zaiste świętości” (por. KKK 492).

${ }_{29}$ Por. M. Lurker, Stownik obrazów i symboli biblijnych, przekł. K. Romaniuk, Poznań 1989, s. $79-80$.

${ }^{30}$ Św. Efrem, Nieskalana, Muza chrześcijańska, t. 1: Poezja armeńska, syryjska i etiopska, red. M. Starowieyski, Kraków 1985, s. 228.

31 Tamże, s. 37.

32 Por. K. Onasch, A. Schnieper, Ikony. Fakty i legendy, Warszawa 2002, s. 256-257.

33 Por. Forster, Świat symboliki chrześcijańskiej, s. 165. 
Źródłem macierzyństwa Maryi jest Jej dziewictwo jako znak niezachwianej wiary i niepodzielnego oddania się woli Bożej. Stała się Matką Zbawiciela, bardziej przez wiarę, niż przez to, że poczęła Go cieleśnie (por. KKK 506). Ten aspekt macierzyństwa podkreślił sam Jezus słowami: „Bo kto pełni wolę Bożą, ten jest Mi bratem, siostrą i matką" (Mk 3,35).

Maryja jest równocześnie Matką wierzących, „ponieważ jest figurą i najdoskonalszą realizacją Kościoła" (KKK 507). Dzięki Jej Boskiemu macierzyństwu wypełnia się proroctwo dane Abrahamowi o potomstwie licznym jak gwiazdy na niebie. Jest pierwszą zbawioną, która zajaśniała na firmamencie nieba, ale jest też gwiazdą najjaśniejszą, ponieważ czynnie współpracowała w dziele zbawienia ludzi i „przez swoje posłuszeństwo stała się nową Ewą, Matką żyjących” (KKK 511).

\section{BIBLIOGRAFIA}

Dąb-Kalinowska B., Ikony. Najpiękniejsze ikony w zbiorach polskich, Olszanica 2008.

Dębowska M., Matka Boża Latyczowska na Wotyniu 1930-1945, Biały Dunajec-Ostróg 2017.

Dębowska M., Obraz Matki Bożej Latyczowskiej w diecezji tuckiej (1930-1945), „Archiwa Biblioteki i Muzea Kościelne", 105 (2016) s. 25-43.

Do Ciebie wołamy, Orędowniczko nasza. Modlitwy i pieśni do Matki Bożej Latyczowskiej, wybór i oprac. H. I. Szumił, Lublin 2016.

Forster D., Świat symboliki chrześcijańskiej. Leksykon, Warszawa 2001.

Historia Cudownego Obrazu Najświętszej Maryi Panny Latyczowskiej znajdującego się w katedrze tuckiej, Łuck 1936.

Historia sztuki, t. 5: Bizancjum i islam, red. D. Fedor, Kraków 2010, s. 26.

Janiec Z., Kult Maryi w Polsce na przestrzeni dziejów. Zarys problematyki, Sandomierz 2013.

Kania J., Miejsca szczególnej czci Matki Bożej na Lubelszczyźnie. Matka Tułaczy i Piastunka Nadziei, „Wiadomości Diecezjalne Podlaskie”, 61 (1992) nr 1-3, s. 73-74.

Katechizm Kościoła Katolickiego, Poznań 1994.

Kobiela S., Matka Boża z chusteczkq - encheirionem, „Series Byzantina”, 5 (2007) s. 34-38. Amalariusz z Metzu, Święte obrzędy Kościoła, II, 24, przekł. zbiorowy, w: Amalariusz z Metzu, Dzieła, t. 1, red. T. Gacia, Lublin 2017, s. 228-229.

Koprowski M., Kresy we krwi, Warszawa 2011.

Krakowiak Cz., Manipularz, w: Encyklopedia katolicka, t. 11, Lublin 2006, kol. 1163.

Lurker M., Słownik obrazów i symboli biblijnych, przekł. K. Romaniuk, Poznań 1989.

Onasch K., Schnieper A., Ikony. Fakty i legendy, Warszawa 2002.

Onasch K., Schnieper A., Ikony. Fakty i legendy, Warszawa 2002.

Surgy P., Przemienienie. Stownik teologii biblijnej, red. X. Leon-Dufour, przekł. K. Romaniuk, Poznań-Warszawa 1985.

Szumił H. I., „Nigdym ja ciebie ludu nie rzuciła”. Z dziejów latyczowskiej Ikony, Sandomierz 2015.

Św. Efrem, Nieskalana, Muza chrześcijańska, t. 1: Poezja armeńska, syryjska i etiopska, red. M. Starowieyski, Kraków 1985. 
Wierna R., Reikonografia obrazu Matki Bożej Latyczowskiej, w: Pod Twoja obronę... Sanktuaria Maryjne na Podolu, red. H.I. Szumił, Sandomierz 2018, s. 87-102.

Wolińska-Wójtowicz A., Matka Boża Latyczowska, Lublin 2014.

Zgierski F., Historyczny opis Cudownego Obrazu Najświętszej Maryi Panny i kościoła w Latyczowie z dodatkiem modlitw i pieśni pobożnych, Kraków 1876.

\section{OBRAZ MATKI BOŻEJ LATYCZOWSKIEJ. ANALIZA I INTERPRETACJA}

\section{Streszczenie}

Obraz Matki Bożej Latyczowskiej jest datowany na XVI wiek, czego nie wykluczają badania konserwatorskie. Prawdopodobnie z Rzymu został już przywieziony między 1594-1597 rokiem, kiedy dominikanie przybyli do Latyczowa (1606), obraz zosta1 umieszczony w kaplicy ufundowanej przez Potockich. W 1648 roku, w obawie przed najazdem Chmielnickiego, dominikanie zabrali obraz do Lwowa. Do Latyczowa powrócił w 1772 roku i pozostał tam do 1917 roku. W czasie pierwszej wojny światowej przebywał w Pietniczanach, a potem w Winnicy, a w 1918 powrócił do Latyczowa i pozostał tam do 1920 roku, kiedy to w obawie przed bolszewikami został wywieziony do Warszawy. Z Warszawy wrócił do kościoła parafialnego w Lubomi (1930-1935), a następnie do kościoła w Łucku (1935-1945). W 1945 roku został przywieziony do Lublina i do 2014 roku znajdował się w kaplicy Sióstr Służek NMP Niepokalanej. W 2014 roku został przeniesiony do kościoła pw. Matki Bożej Różańcowej w Lublinie. W ciągu swej historii, obraz był kilkakrotnie restaurowany, ale nie zachowała się szczegółowa dokumentacja prac konserwatorskich. Ostatnią gruntowną renowację przeprowadzono w 2014 roku, w pracowni konserwatorskiej w Lublinie. Obraz Matki Bożej Latyczowskiej został wykonany $\mathrm{w}$ technice tempery (ewentualnie $\mathrm{z}$ domieszką oleju) na płótnie naciągniętym na deskę. Posiada wymiary 128,5×92 cm. Przedstawia Maryję w pozycji stojącej, w ujęciu do kolan. Obraz jest kopią ikony Salus Populi Romani. Wizerunki te pojawiły się w Polsce pod koniec XVI wieku . Przeszły one pewną ewolucję przedstawienia pod wpływem malarstwa zachodniego. Układ kompozycyjny latyczowskiego obrazu jest wiernie powtórzony z dzieła rzymskiego.

Słowa kluczowe: Matka Boża Latyczowska; Salus Populi Romani; ikona; Lublin; Latyczów 


\title{
THE PAINTING OF OUR LADY OF LATYCZÓW. AN ANALYSIS AND INTERPRETATION
}

\begin{abstract}
Summary
The painting of Our Lady of Latyczów dates back to the 16th century, and the examination of the painting did not prove otherwise. It was reportedly brought from Rome between 1594-1597 when the Dominicans arrived at Latyczów (1606); the painting was placed in the chapel funded by the Potocki family. In 1648, being in fear of Chmielnicki's invasion, the Dominicans took the painting to Lviv. It returned to Latyczów in 1772 and was there until 1917. During World War I, it was in Pietniczany, and then in Winnica, and in 1918 it returned to Latyczów and was there until 1920 when it was transferred to Warsaw to be protected from the Bolsheviks. Then it returned from Warsaw to the parish church in Lubomia (1930-1935), and subsequently to the church in Luck (1935-1945). In 1945 it was transferred to Lublin to the chapel of the Congregation of the Sisters Servants of Mary Immaculate, from where it was taken, in 2014, to the church dedicated to Our Lady of the Rosary in Lublin. The painting was renovated a few times, but detailed documentation of the conservation did not survive. The last thorough renovation was done in Lublin in 2014. The painting of Our Lady of Latyczów was painted in the tempera technique (possibly with the admixture of oil) on canvas stretched on a board. It measures $128,5 \times 92 \mathrm{~cm}$. The painting depicts Holy Mary in a standing position with a view of her figure to her knees. It is a copy of the icon of Salus Populi Romani, which appeared in Poland at the end of the 16th century. The depiction, however, underwent some evolution under the influence of Western painting. The composition of the Latycz painting is identical with the Roman work.
\end{abstract}

Keywords: Our Lady of Latyczów; Salus Populi Romani; an icon; Lublin; Latyczów 